\title{
DOES CREDIT ACCESS IMPROVE ADOPTION INTENSITY OF IMPROVED MAIZE SEED VARIETIES?
}

\author{
Ayodeji Damilola KEHINDE, ${ }^{1, *}$ \\ *E-mail: kehindeayodeji8@gmail.com
}

Received: Aug. 26, 2020. Revised: Nov. 23, 2020. Accepted: Dec. 15, 2020. Published online: Jan. 29, 2021

\begin{abstract}
This study investigated the effect of credit access on the adoption intensity of improved maize varieties in Osun State. A number of 150 maize farmers were selected through a multistage sampling procedure from using a structured questionnaire. Descriptive statistics, adoption index, and Tobit regression model were used to analyse the data collected. The results showed that Majority of maize farmers were over 40 years (52.6\%), male (87\%), and married (87\%). The result also showed that majority of the farmers did not adopt improved maize varieties (55\%) in the state. Swan 1 improved variety was majorly adopted (87.1\%), while DMRESR-W variety was less adopted (62.9\%) in the State. Just a few of maize farmers had access to credit in the State (20\%). The mean adoption intensity in the State was observed to $62 \%$. Based on adoption intensity of improved maize varieties, adopters were classified as partial adopters (65\%) and full adopters (35\%).
\end{abstract}

Tobit regression estimates showed that credit access, household size, secondary occupation, years of education and extension contact have significant effect on the adoption intensity of improved maize varieties. In accordance with the findings, we therefore recommend that microfinance institutions should look attentively at scaling up their credit services to enhancing adoption intensity of improved maize varieties.

Keywords: microfinance; Swan I; DMRESR-W; Tobit model; maize farmers, Osun State.

\section{INTRODUCTION}

Maize is among major staple food crops grown and consumed widely across all States in Nigeria including Osun State, due to its ability to thrive under different ecological conditions (Afzal, 2007). In this regard, maize is one of most important crops

\footnotetext{
${ }^{1}$ Department of Agricultural Economics, Faculty of Agriculture, Obafemi Awolowo University, lle Ife, Osun State, Nigeria
} 


\section{EFFECT OF CREDIT ACCESS ON ADOPTION INTENSITY OF IMPROVED MAIZE VARIETIES}

in Nigeria, providing food for human beings and feeds for animals (Sule Enyisi et al., 2014). Maize could also serve as raw materials for agroindustries, such as flour mills, breweries, confectionaries and animal feed industries (Afzal, 2007). Sequel to this, maize has reached the status of commercial crop because many agrobased industries demand for maize in large quantities for their production (Iken and Amusa, 2004). However, Kudi et al. (2011) have shown that maize actual yields are low, as compared to potential yields. This implies that maize is not produced in sufficient amounts in order to meet up with the household and industrial needs of the country. This could be partly attributed to the fact that maize production is fraught with numerous constraints, such as disease, pest and weed infestation (Komolafe and Adeoti, 2018). This led to the quest to develop improved maize varieties, which has been of high priority to farmers and researchers (Welch and Graham, 2004; Juma, 2010). This was necessitated not for increased yield alone, also for achieving food security and improved nutrition (HarvestPlus, 2012).

Over the years, International Institute of Tropical Agriculture(IITA), in collaboration with Government and other national partners, has developed and disseminated a lot of improved maize varieties that are of high grain and yields, resistant to insects, pests and diseases attack (Alene and Manyong, 2007). Despite this attempt, little success is recorded as regards the adoption rates. Several studies
(Adekambi et al., 2009; Conley and Udry, 2010; Donstop et al., 2011; Adenuga et al., 2014) had pointed out that adoption rate is low, as a result of some set of factors, serving as barriers to adoption. Therefore, identifying the factors is very germane to improving the adoption rate, and could consequently improve the livelihood of farmers (Foster and Rosenzweig, 2010). Two factors are the most prominent barriers of adoption, namely poor access to credit and market failure (Farrin and Miranda, 2015). Studies, such as Karlan et al. (2012), Fadare et al. (2014), Farrin and Miranda (2015), Mishra and Sam (2016) separately affirmed that access to credit is the key determinant of innovation/technology adoption. Dzadze et al. (2012) submitted that except credit is made accessible to farmers on appropriate and suitable terms, most farmers will be extremely handicapped in adopting innovation.

The understanding that credit access could enhance the adoption of improved seed varieties among maize farmers, especially the smallholders, led successive Governments of Nigeria to step up efforts to establish agricultural credit programmes for provision of low interest rate credit to smallholder farmers in Nigeria. This is necessary to sufficiently encourage efficient adoption of new agricultural technologies and innovations through boosting the farmers' risk bearing ability to adopt even riskier technologies. However, the reports from these programmes revealed that the expected impact has not been felt 


\section{A.D. KEHINDE}

due to inability of farmers to access the credit. This has great implication on the adoption of improved maize varieties, food production and of course, in meeting one of the millennium development goal of poverty eradication.

In the light of this, this paper focuses on effect of credit access on the adoption intensity of improved maize varieties. Specifically, estimated the adoption intensity of improved maize varieties and determined effect of credit access on the adoption intensity of improved maize varieties.

\section{MATERIALS AND METHODS}

\section{Research methodology}

The study was carried out in Osun State, a state located in the southwestern part of Nigeria. Osun State shares boundary with Kwara State in the north,
Ondo and Ekiti States in the east, Ogun State in the South and Oyo State in the West. The state was selected because of the abundance of maize farmers. Osun State is located at coordinates $7^{0} 30^{\prime} \mathrm{N}$ and $4^{0} 30^{\prime} \mathrm{E}$ with a population size of about $3,423,535$ people, a landmass of 10,245 $\mathrm{km}^{2}$ and a population density of 334 (National Population Commission, 2006). Osun State is in the rain forest zone with average annual rainfall of not less than $168 \mathrm{~cm}$ (66 in), even though it typically lies between $175 \mathrm{~cm}$ (69 in) and $200 \mathrm{~cm}$ (79 in). The wet and dry seasons are distinct; the wet season is between March and October, while the dry season is between November and February. Osun State comprises three agro-ecological zones: rainforest (Ife-Ijesa), derived savanna (Osogbo), and Guinea Savanna (Iwo) zones. The food crops grown in the state include cassava, maize, yam, cocoyam, and rice, while the permanent crops include kola nut, cocoa, oil palm, cashew, mango, plantain and banana.

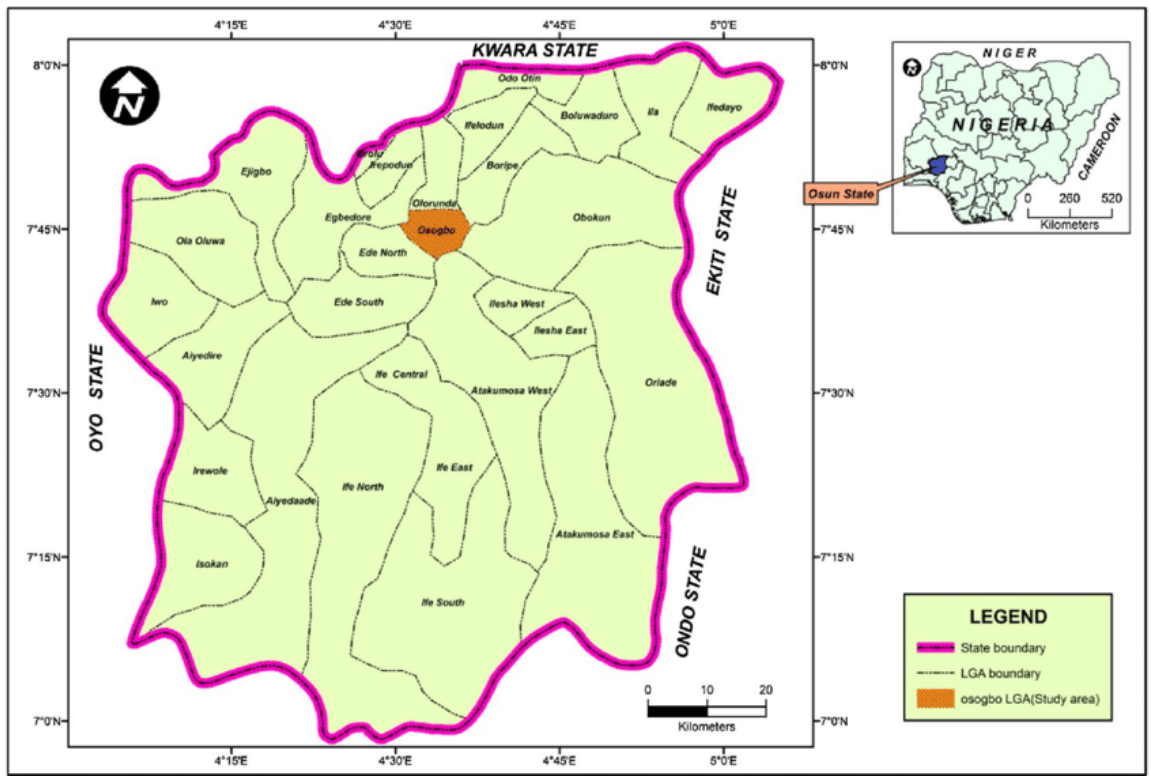

Map of Osun State 


\section{EFFECT OF CREDIT ACCESS ON ADOPTION INTENSITY OF IMPROVED MAIZE VARIETIES}

A multi-stage sampling procedure was used to obtain data for the study. In the first stage, two agricultural zones were selected out of the three zones in Osun State using simple random sampling. The zones are rainforest (Ife-Ijesa) and Guinea Savanna (Iwo), agricultural zone. The second stage involved simple random selection of three local government areas in each zone. Thereafter in the third stage, five villages were selected using simple random techniques.

In the final and last stage, five maize farmers were selected from the villages. A total of 150 maize farmers were selected for the study. Information were collected on the respondents' socio-economic characteristics, such as age, educational level, household size, sex, farm size, secondary occupation among others.

\section{Analytical framework Adoption index}

This study employed the index by Ademuluyi (2014). Adoption index was used to determine the adoption intensity of improved maize varieties among farmers. This study adopted the area of land used for improved maize varieties as a proportion to the total land area for individual maize farmers, as proxy for intensity of use of improved maize varieties.

$$
\mathrm{A}_{\mathrm{I}}=\frac{\sum_{i=1 \mathrm{Ri}}^{n} \mathrm{R}}{\sum_{i=1}^{n} \mathrm{RT}}
$$

where, $A_{l}$ is the adoption level for individual maize farmers, $\mathrm{Ri}$ is the area of land used to cultivate improved maize varieties (hectare), RT is the total area of land of maize farm.

The mean adoption intensity was calculated using this formula:

$$
\text { Mean adoption intensity }=\frac{\Sigma \mathrm{fx}}{\mathrm{n}}
$$

where, $f$ is the frequency of variable $x$; $\mathrm{N}$ is number of the variable $\mathrm{x}$.

\section{Tobit regression model}

The Tobit model is a hybrid of binary and continuous model, which simultaneously analyzes the decision to adopt and the adoption intensity.

According to Tobin (1958), a typical tobit model is expressed by the following relationship:

$$
Y=X \beta+u
$$

where, $Y$ is the dependent variable, $X$ is vector of independent variables, $\beta$ is coefficient of independent variable, and $\mathrm{u}$ is an independent variable distributed error term assumed to be normal with zero mean and constant variance $\sigma^{2}$.

Tobit model undertakes a fundamental assumption that stochastic index equal to $(X \beta+u)$, which is observable only when it is positive, and hence qualifies as latent variable. Therefore, the expected value of $y$ is

$$
\mathrm{E}(\mathrm{y})=\mathrm{X} \beta \mathrm{F}(\mathrm{Z})+\sigma f(\mathrm{z}),
$$

where, $Z=X \beta / \sigma, f(Z)$ is the unit normal density, and $F(Z)$ is the cumulative normal distribution function.

However, Tobit coefficients don't directly measure the correct regression coefficient above the limit, they only provide information that is commonly realized. However, the technique can be decomposed to determine both changes in probability of being above the limit and changes in the value of the dependent variable if it is already above the limit. This will give some useful and insightful deductions about the estimation under study (McDonald and Moffit, 1980).

According to McDonald and Mofit (1980), the equation (4) can be decomposed by considering the effect of a change in the ith variable of $\mathrm{X}$ on $\mathrm{Y}$ : 


$$
\begin{gathered}
\delta \mathrm{Ey} / \delta \mathrm{X}_{\mathrm{i}}=\mathrm{F}(\mathrm{Z})\left(\delta \mathrm{Ey}^{*} / \delta \mathrm{X}_{\mathrm{i}}\right)+\mathrm{Ey} \mathrm{y}^{*}\left(\delta \mathrm{F}(\mathrm{Z}) / \delta \mathrm{X}_{\mathrm{i}}\right) \\
\text { The empirical model is specified as follows: } \\
\mathrm{Y}^{*}=\beta_{0}+\beta_{1} X_{1}+\beta_{2} \mathrm{X}_{2}+\beta_{3} X_{3}+\beta_{4} X_{4}+\beta_{5} \mathrm{X}_{5}+\ldots+\beta_{12} X_{12}+\varepsilon
\end{gathered}
$$

$Y=$ adoption intensity. In this study, the dependent variable is the adoption intensity generated from adoption index, which ranges from (0 to 1$)$.

The definitions of independent variable are: $\mathrm{X}_{1}=$ Gender (male $=1$, female $=0$ ); $X_{2}=$ Credit access (if yes $=1,0=$ if no); $X_{3}=$ Household size (number of people in the house); $X_{4}=$ Age (Years); $X_{5}=$ Year of Education (number of years spent in school); $X_{6}=$ Co-operative membership (if yes $=1,0=$ if no); $X_{7}=$ Seed source $(1=$ research institute or other formal source; $0=$ if otherwise); $\mathrm{X}_{8}=$ Extension contact (number of visit); $X_{9}=$ Farming experience (years); $X_{10}=$ Secondary occupation $(1=$ if the respondent engages in secondary occupation; $0=$ if otherwise); $\mathrm{X}_{11}=$ Number of credit sources (actual number of sources); $\mathrm{X}_{12}=$ Yield $(\mathrm{kg})$.

\section{RESULTS AND DISCUSSION}

\section{Socio-economic characteristics of maize farmers}

The socio-economic features of maize farmers are presented in Table 1. Most of the maize farmers in Osun State are male (87\%). This result reveals that maize farming is dominated by males. Male farmers were found to be the ones cultivating maize farm, this can be attributed to the fact that male farmers have better access to resources, such as credit, land among others. This agrees with the study of Ademiluyi (2014). Majority of the maize farmers fall within the age group of $20-30$ years
(30\%). This shows that maize farmers are young and vibrant. This implies higher likelihood of these farmers adopting new innovations because of their higher risk-taking behavior. This is line with Simtowe et al. (2007). About $87 \%$ of the respondents were married. This indicates that married people dominate maize farming in Osun State. Most of the farmers have family size of 1 to 5 household members (48.6\%). This implies that maize farmers do not have enough members to assist in farming activities, hence they may likely adopt innovation to advance their productivity and food security. This is in support of the findings showed by Nnadi and Akwiwu (2006). Majority of maize farmers have secondary education (57.1\%). This shows considerable literacy level among the farmers. Literate farmers are expected to adopt innovation (Siyanbola, 2012). Majority of the maize farmers (52.9\%) have the farming experience between 11-20 years. This implies that the maize farmers have many years of farming experience. Experienced farmers are expected to adopt innovation (Langya and Mekura, 2005). Only $48.6 \%$ of the maize farmers have contact with extension agents. This reveals that maize farmers have been starved with necessary information relevant to adoption of innovation. This is in accordance with Ademiluyi (2014). 


\section{EFFECT OF CREDIT ACCESS ON ADOPTION INTENSITY OF IMPROVED MAIZE VARIETIES}

Just a few of the respondents (20\%) had access to credit. This suggests that majority of maize farmers might find it difficult to adopt innovation. Majority of maize farmers (64.3\%) buy seeds from the market, which may likely not be a reliable source of improved seeds. This implies that maize farmers might still be planting traditional maize varieties and still be suffering from unnecessary problems. Majority of maize farmers (58.6\%) have more than 2 hectares. This implies that though the farmers are smallholders, they have land assets to adopt new technology. A similar result was reported by Amsalu and De Graaf (2007).

Table 1 - Socio-economic characteristics of farmers

\begin{tabular}{lc}
\hline Variables & Maize farmers \\
\hline Male $(\%)$ & 87.1 \\
\hline Age $(\%)$ & 30 \\
\hline $20-30$ & 17.4 \\
\hline $31-40$ & 28.6 \\
\hline $41-50$ & 4.3 \\
\hline $51-60$ & 17.1 \\
\hline Above & 12.9 \\
\hline Marital status (\%) & 87.1 \\
\hline Single & \\
\hline Married & 48.6 \\
\hline Household size (\%) & 43.1 \\
\hline $1-5$ & 4.2 \\
\hline $6-10$ & 1.4 \\
\hline $11-15$ & 30 \\
\hline Above 16 & 57.1 \\
\hline Education (\%) & 12.9 \\
\hline Primary & 52.9 \\
\hline Secondary & 31.5 \\
\hline Tertiary & 14.3 \\
\hline Farming experience $(\%)$ & 1.4 \\
\hline $1-20$ & 48.6 \\
\hline $21-40$ & 20 \\
\hline $41-60$ & 28.6 \\
\hline Above 61 & 64.3 \\
\hline Extension visit (\%) & 7.1 \\
\hline Access to credit (\%) & 10 \\
\hline Seed source (\%) & 31.4 \\
\hline Ministryl ADP & 58.6 \\
\hline Market & \\
\hline Stocks from previous harvest & \\
\hline Farm size (\%) & \\
\hline Less than1 hectares & \\
\hline $1-2$ hectares & \\
\hline Above 2 hectares & \\
\hline & \\
\hline
\end{tabular}

Source: Field Survey, 2018 


\section{A.D. KEHINDE}

Adoption typology of improved maize varieties

In this study, an adopter is defined as a farmer who invests on improved maize varieties. About $45 \%$ of the respondents adopted improved seed varieties (Fig. 1). This implies that the uptake of improved maize varieties is low in Osun State. The farmers are still using traditional maize varieties.

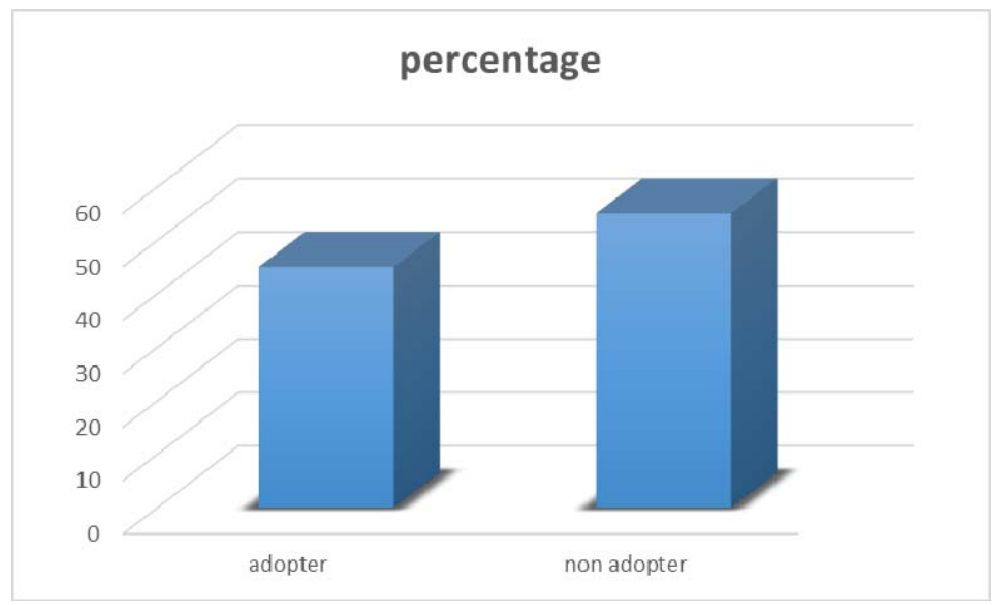

Source: Field Survey, 2018

Figure 1 - Adoption typology of improved maize varieties

\section{Improved maize varieties} grown in the study area

Table 2 presents the improved maize varieties grown by the farmers; $87.1 \%$ out of the $100 \%$ farmers grow Swan 1, while $62.9 \%$ out of the $100 \%$ farmers grow DMR-ESR-W. This result indicates that majority of the farmers adopt Swan 1. This is attributed to the fact that Swan 1 has high yields, and resistance to insects, pests and diseases traits.

Table 2 - Improved maize varieties cultivated

\begin{tabular}{cc}
\hline Improved maize varieties & Percentage \\
\hline Swan I & 87.1 \\
\hline DMR-ESR-W & 62.9 \\
\hline
\end{tabular}

Source: Field Survey, 2018

*Multiple responses from some respondents
Adoption intensity of improved maize varieties

Adoption intensity of improved maize varieties are presented in Fig. 2. The average adoption intensity was observed to be $62 \%$. Based on the mean percentage, the adoption intensity was categorized into two: partial adopters with adoption intensity less than $62 \%$ and full adopters with adoption intensity greater than $62 \%$. Based on adoption intensity of improved maize varieties, adopters were classified as partial adopters (65\%) and full adopters (35\%). This means that improved maize varieties had not made an appreciable headway in the Osun State, stressing the fact that most farmers still make use of traditional maize varieties. 


\section{EFFECT OF CREDIT ACCESS ON ADOPTION INTENSITY OF IMPROVED MAIZE VARIETIES}

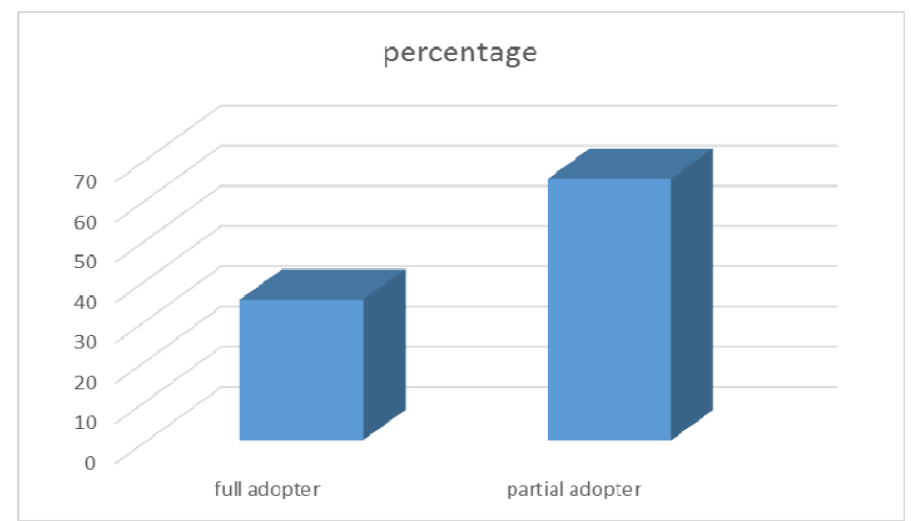

Source: Field Survey, 2018

Figure 2 - Adoption intensity of improved maize varieties

Effect of credit access on adoption intensity of improved maize varieties

Table 3 shows the Tobit estimates of the effect of credit access on adoption intensity of improved maize varieties. The model simultaneously investigated the effect of credit access on probability and intensity of adoption of improved maize varieties. The model is significant at $1 \%$. This implies that there is about $99.99 \%$ assurance that the model was not misspecified. The estimates show that credit access, years of formal education, extension contact, and secondary occupation were statistically significant factors influencing adoption intensity of improved maize varieties. The coefficient of credit access was positive and significant. This shows that a unit increase in credit access increases the adoption intensity by 0.147 units. This implies that credit access from governments or microfinance agencies would increase the likelihood of adoption of improved maize varieties. This is in line with the study of Simtowe and Zeller (2007). The coefficient of household size was positive and significant. This shows that a unit increase in household size increases the adoption intensity by 0.31 units. This implies that large households incline adoption intensity of improved maize varieties. This is in line with the study of Nnadi and Akwiwu (2006). Years of education had positive coefficient and significant. This suggests that as farmers' years of education increases the adoption intensity by 0.018 units. This is line with study by Genanew and Alemu (2012). This implies literate farmers would adopt improved maize varieties. Extension contact had positive coefficient and significant. This implies that extension contact increases the adoption intensity by 0.128 units. Households with regular contact with extension agents are more enlightened through advisory services. Therefore, they would appreciate benefits of new technology 


\section{A.D. KEHINDE}

and, consequently, adopt the new technologies (Knowler and Bradshaw, 2007). Secondary occupation had negative coefficient and significant. This suggests that secondary occupation decreases the adoption intensity by 0.157 units. This implies farmers with secondary occupation would not adopt improved maize varieties.

Table 3 - Effect of credit access on adoption intensity of improved maize varieties

\begin{tabular}{lccccc}
\hline Variables & Coefficient & dy/dx & S.E. & $\mathbf{Z}$ & $\boldsymbol{p}>|\mathbf{z}|$ \\
\hline Constant & $0.551^{\prime \prime}$ & & 0.233 & 2.36 & 0.022 \\
\hline Gender & -0.064 & -.057 & 0.102 & -0.56 & 0.574 \\
\hline Credit access & $0.164^{* *}$ & 0.147 & 0.065 & 2.25 & 0.024 \\
\hline Household size & $0.034^{*}$ & 0.031 & 0.015 & 1.95 & 0.051 \\
\hline Age & -0.005 & -0.004 & 0.004 & -1.02 & 0.306 \\
\hline Years of education & $0.020^{* *}$ & 0.018 & 0.007 & 2.40 & 0.016 \\
\hline Cooperative membership & 0.061 & 0.054 & 0.069 & 0.79 & 0.429 \\
\hline Seed source & 0.049 & 0.044 & 0.079 & 0.56 & 0.573 \\
\hline Extension contact & $0.144^{\prime \prime}$ & 0.128 & 0.063 & 2.04 & 0.041 \\
\hline Farming experience & -0.002 & -0.002 & 0.003 & -0.52 & 0.605 \\
\hline Secondary occupation & $-0.176^{*}$ & -0.157 & 0.090 & -1.74 & 0.081 \\
\hline Number of Credit sources & -0.079 & -0.071 & 0.077 & -0.92 & 0.357 \\
\hline Yield & -0.004 & -0.003 & 0.003 & -0.97 & 0.331 \\
\hline LRchi2 (12) =36.09 Prob>chi2=0.004 & & & & \\
Pseudo R2 = 0.52 & & & & & \\
\hline
\end{tabular}

**, * variables significant at 5\%, 10\%; Source: Field Survey, 2018

\section{CONCLUSIONS}

This study investigated the effect of credit access on adoption intensity of improved maize varieties in Osun State. A multistage sampling procedure was used to obtain data for the study. Descriptive analysis, adoption index, and tobit regression model were used to analyze the data collected. This study concluded that maize farmers were male, smallholders and at their productive age. The study also concluded that the adoption of improved maize varieties is low and had not made an appreciable headway in Osun State. Also, majority of the farmers adopt
Swan 1, compared to DMR-ESR-W variety. Credit access along with years of formal education, extension contact, and secondary occupation are statistically significant factors influencing adoption intensity of improved maize varieties. All these significant variables should be considered in an effort of up taking improved maize varieties in the area under study.

It is therefore recommended that microfinance institutions should look attentively at scaling up their credit services to enhancing adoption intensity of improved maize varieties. In addition, extension services should be made available to the farmers in 


\section{EFFECT OF CREDIT ACCESS ON ADOPTION INTENSITY OF IMPROVED MAIZE VARIETIES}

order to sensitized them on the use of improved maize varieties, as well as to ensure adequate and timely ease of credit access. The results of the study also suggest that educated farmers easily adopt improved maize varieties. Programmes on adoption of improved maize varieties should focus educated farmers with large households.

\section{REFERENCES}

Ademiluyi, I.O. (2014). Adoption of improved maize varieties among farmers in Bassal Local government area of Plateau State, Nigeria. Int.J. Innovative.Agric.Biol.Res., 2(4): 2633.

Adenuga, A.H., Omotesho, O.A., Ojehomon, V.E.T. \& Diagne, A. (2014). Determinants of adoption of improved rice varieties in selected local government areas in Nasarawa State, Nigeria. Ife Journal of Agriculture, 27(1): 25-34.

Afzal, M. (2007). The impact of globalization on economic growth of Pakistan. Pak.Dev.Rev., 46(4): 723-734

Alene, A.D. \& Manyong, V.M. (2007). Gains from high-yielding varieties with and without complementary technologies: the case of improved cowpea in Northern Nigeria. J.Agric. Food Econ., 2(1): 1-14.

Amsalu, A. \& De Graaf, J. (2007). Determinants of adoption and continued use of stone terraces for soil and water conservation in an Ethiopia highland watershed. Ecol. Econ., 61(2-3): 294-302, DOI: 10.10 16/j.ecolecon.2006.01.014

Adekambi, S.A., Diagne, A., Simtowe, F. \& Biaou, G. (2009). The impact of agricultural technology adoption on poverty: The case of Nerica rice varieties in Benin. A shorter version of the paper is being presented as contributed paper at the 27th Conference of the International
Association of Agricultural Economists, Beijing, China, pp. 116, DOI: 10.22004/ag.econ.51645

Conley, T.G. \& Udry, C.R. (2010). Learning about a new technology: pineapple in Ghana. Am.Econ.Rev., 100(1): 35-69.

Donstop-Nguezet, P.M., Diagne, A., Okoruwa, V.O. \& Ojehomon, V.E.T. (2011). Impact of improved rice technology adoption (NERICA varieties) on income and poverty among rice farming households in Nigeria: A local average treatment effect approach. Q.J.Int.Agric., 50(3): 267-291.

Dzadze, P., Osei Mensah, J., Aidoo, R. \& Nurah, G.K. (2012). Factors determining access to formal credit in Ghana: A case study of smallholder farmers in the AburaAsebu-Kwamankese district of central region of Ghana. J.Dev. Agric.Econ., 4 (14), 416-423, DOI: 10.5897/JDAE12.099

Fadare, O.A., Akerele, D. \& Toritseju B. (2014). Factors influencing adoption decisions of maize farmers in Nigeria. IJFAEC, 2(3): 45-54, DOI: 10.22004/ag.econ.186266

Farrin, K. \& Miranda, M.J. 2(015). A heterogeneous agent model of credit-linked Index insurance and farm technology adoption. J.Dev. Econ., 116, 199-211, DOI: 10.1016/ j.jdeveco.2015.05.001

Fernandez-Cornejo, J. \& McBride, W. (2002). Adoption of bioengineered crops (Agricultural Economics Report No. 810). Washington, DC: US Department of Agriculture Economic Research Service (USDAERS).

Foster, A.D. \& Rosenzweig, M.R. (2010). Microeconomics of technology adoption. Annu.Rev.Econ., 2(1): 395-424, DOI: 10.1146/annurev.eco nomics.102308.124433

Genanew, B.W. \& Alemu, M. (2012). Investment in land conservation in Ethiopia highlands: a household plot-level analysis of the roles of 


\section{A.D. KEHINDE}

poverty, tenure security and market incentives. IJEF, 4(6): 32-50, DOI: 10.5539/ijef.v4n6p32

HarvestPlus (2014). Kigali declaration on biofortified nutritious foods. Second Global Conference on Biofortification, Kigali, Rwanda. http://biofortconf.ifpri. info/files/2014/04/Kigali-Declarationon-Biofortified-Nutritious-Foods-pdf

Iken, J.E. \& Amusa, N.A. (2004). Maize research and production in Nigeria. Afr.J.Biotechnol., 3(6): 302-307, DOI: 10.5897/AJB2004.000-2056

Juma, C. (2010). The new harvest: Agricultural innovation in Africa. Oxford University Press.

Karlan, D., Osei, R., Osei-Akoto, I. \& Udry, C. (2012). Agricultural decisions after relaxing credit and risk constraints, Center for Global Development, Working Papers 310.

Knowler, D. \& Bradshaw, B. (2007). Farmers' adoption on conservation agriculture: $A$ review and synthesis of recent research. Food Policy, 32(1): 25-48, DOI: 10.1016/j.foodpol. 2006.01 .003

Komolafe, J.O. \& Adeoti, I.A. (2018). Influence of social capital on the use of improved maize seed among farmers in southwestern Nigeria. Int.J.Agric.For., 8(3): 129-138, DOI: 10.5923/j.jjaf.20180803.03

Kudi, T.M., Bolaji, M., Akinola, M.O. \& Nasa'I,D.H. (2011). Analysis of adoption of improved maize varieties among farmers in Kwara State, Nigeria. IntJ. Peace Dev.Stud., 1(3): 8-12.

Langy, A. \& Mekura, M. (2005). Modelling agricultural technology adoption using the software STAT. A paper presented at a training course organized by CIMMUTALP for its NARS partners in Southern Africa on econometric application of modelling technologies.

McDonald, J. F. and. Moffit, R. A (1980). The uses of Tobit analysis. The review of econometrics and statistics. In: Kristjanson, P., Okike, I., Tarawali S., Singh, B. B. and V. M. Manyong (2005). Farmers' perception of benefits and factors affecting the adoption of improved dual-purpose cowpea in the dry savannas of Nigeria. Journal of Agricultural Economics, vol. 32, pp 195-210.

Mishra, K. \& Sam, A. G. (2016). Does women's land ownership promote their empowerment? Empirical Evidence from Nepal. World Development, 78, 360-371.

National Population Commission (NPC) (2006). Human population figures of 2006 census in Nigeria.

Nnadi, F.N. and Akwiwu, C.D. (2006). Adoption of proven soil management practices by rural women in Imo state, Nigeria. International Journal of Natural and Applied Sciences, 2 (3), 262-267.

Simtowe, F., Zeller, M. \& Diagne, A. (2007). The impact of credit constraints on the adoption of hybrid maize in Malawi. RAEStud., 90(1): 15-22.

Siyanbola, A.A. (2012). Investigating the determinants of appropriate use of microcredit by poultry in Western Nigeria, Br.J.Poult.Sci., 1(1): 01-04, DOI: 10.5829/idosi.bjps.2012.1.1.5

Sule Enyisi, I., Umoh, V.J., Whong, C.M.Z., Abdullahi, I.O. \& Alabi, O. (2014). Chemical and nutritional value of maize and maize products obtained from selected markets in Kaduna State, Nigeria. AJFST, 5(4): 100-104, DOI: 10.14303/ajfst.2014. 029

Tobin, J. (1958). Estimation of relationships for limited dependent variables, Economitrica 26(1): 24- 36

Welch, R.M. \& Graham, R.D. (2004). Breeding for micronutrients in staple food crops from a human nutrition perspective. J.Exp.Bot., 55(396): 353-364, DOI: 10.1093/jxb/erh064. 